\title{
Impact of Covid-19 Pandemic on Mses and Cooperatives and Strategic Recovery in New Normal Era
}

\author{
Dahri Tanjung* \\ Agribusiness Management, School of Vocational Studies, Bogor University \\ e-mail: ir.da@apps.ipb.ac.id \\ Yeti Lis Purnamadewi \\ Department of Economics, Faculty of Economics and Management, Bogor University \\ e-mail: yetilispurnama@yahoo.com
}

\begin{abstract}
The purpose of this study is to examine the economic impact of Covid-19 on the performance of micro, and small enterprises (MSEs) and cooperative institutions; how the strategies and formulate a recovery strategy in the new normal era. The main data used are primary data collected through interviews to MSE and microfinance institutions. The analytical method used is descriptive statistics and econometric models. The before and after analysis shows the significantly different costs and benefits of MSEs before and after the pandemic. The analysis shows that in the pandemic Covid-19 period, all MSEs decreased performance, most experienced a decrease in business turnover (6 percent) and similarly with cooperative institutions, their turnover decreased to 55\%. The strategy of the cooperatives to maintaining its performance is to provide relaxation, improve efficiency by reducing employees, and ask for a reduction in profit-sharing payments to creditors; while the MSE strategy if the cooperatives does not provide loans for a while is 60 percent of MSEs seeking loans from relatives, 25 percent borrowing from other microfinance despite high-interest rates and 15 percent selling their household assets.
\end{abstract}

Keywords: Covid-19, MSE, cooperative, new normal era, strategic recovery. 


\section{INTRODUCTION}

The Covid-19 outbreak has caused tremendous negative impacts on various sectors, especially health and the economy. The slowdown in economic growth due to the implementation of large-scale social distancing (PSBB) policies such as social distancing and others has an impact on decreasing household consumption, investment, and exports as well as increasing unemployment and poverty rates. Although this policy is a precautionary measure to limit the spike in the spread of Covid-19 by controlling the movement of the community, such as dismissing school and work activities, restricting religious activities, and limiting activities in public places or facilities; unfortunately, it leads to disruption in the economy. Albulescu (2020) states that several important sectors such as trade, tourism, transportation, education and health are the sectors most affected.

Especially for the micro and small scale business (MSEs) sector, which has been a safety net, currently it is one of the economic sectors most affected by Covid-19 due to the absence of activities outside the home by the community. On the other hand, the MSEs sector is a sector that has the potential to be moved because it has wide market opportunities and is able to absorb a lot of workers (Pakpahan, 2020). Like the results of research in Pakistan, they found that, on average, weekly sales and household income both fell about $90 \%$ (Malik et al, 2020).

In terms of capital, so far, one of the sources of capital for MSE is from microfinance institutions such as cooperatives. When MSE have problems, the savings and loan process with the cooperative institutions is disrupted. Because the turnover of MSE has decreased, the turnover of cooperatives has been affected, namely during the Covid-19 period it fell by around 55 percent. In many cases, credit payments by MSEs have stalled, resulting in a sharp increase in non-performing loans.

Especially in Bogor, over the past five years (2015-2019) the economic structure it is dominated by five (5) categories of the industry, including: Manufacturing; Wholesale and Retail Trade, Car and Motorcycle Repair; Construction; Agriculture, Forestry and Fisheries as well as Transportation and Warehousing (Statistic of Bogor District, 2019). This can be seen from the role of each business field in the formation of Gross Regional Domestic Product (GRDP) Bogor District. Likewise with the Bogor City, the structure of the economy is dominated by five categories of the industry, namely: Wholesale and Retail Trade, Repair Cars and Motorcycles; Processing industry; Transportation and Warehousing; Construction; as well as Financial Services and Insurance (Statistic of Bogor City, 2019).

Furthermore, businesses in Bogor, mostly by enterprises classified as micro, small and medium with number as many as 2,428 units were registered on the number around 700.000 units. While in the Bogor Municipality, the number of SMEs which recorded as many as 23.706 units.

When compared the pandemic Covid-19 crisis (2020) with the monetary crisis in 1998 and 2008, is rather different. During the 1998 economic crisis, SMEs were relatively unaffected by the global economic turmoil and multidimensional crises because not many business actors had contact with exchange rates and almost no SMEs made loans in foreign currency. Meanwhile, in 2008, many SMEs had borrowed in foreign currency, so they were easily affected. However, SMEs will not be carried away by the impact of the global economic turmoil too deeply. This is because Indonesian entrepreneurs are experienced in dealing with economic dynamics. In addition, during the 2008 economic crisis, the purchasing power of Indonesians was well maintained (Miswanto \& Vajrin, 2019).

Furthermore, if the 2008 monetary crisis is compared to the Covid19 crisis in 2020 (health crisis), then the impact on SMEs is very pronounced. People are prohibited doing activities, so offline activities have decreased dramatically, while SME business activities are generally offline activities.

On the other hand, micro credit and rural banks (Bank Perkreditan Rakyat) are basically quite resilient compared to larger forms of financial institutions, especially in the face of the economic crisis. Two global crisis events that occurred in 1997/1998 and 2008, rural banks 
demonstrated its resilience. In the event of the crisis, major financial institutions, including large banks experienced a very strong shock and needed Central Bank intervention to save. Although strong impact, but the crisis is not to create a significant shock. In the global era, the potential for an economic crisis is even greater to hit countries in the world, including Indonesia. Since the opening of globalization, the Indonesian economy has repeatedly experienced waves of crises, both large and small, as a result of economic problems that have occurred in various parts of the world economy. The crisis that occurred in America in 2008 and that occurred in Europe in 2010/2011 had a strong enough impact on the business world, including banking business in Indonesia, including rural banks (Lestari, 2014).

The question is how depth the impact of the Covid-19 pandemic crisis has on MSEs businesses and savings and loan cooperative financial institutions in the Bogor District and Bogor City. What factors cause bad loans of MSEs and cooperative institutions and what strategies need to be taken so that the MSEs quickly recover from the impact Covid-19?. The novelty of this study is to link the impact of pandemic Covid-19 not only to MSEs or the impact of pandemic Covid-19 on cooperative, but also to link MSEs with cooperative as well as their source institution for financing. Thus, the MSEs studied are directly related to their microfinance institutions. Besides that, the analysis used is also a quantitative analysis which is still relatively rarely used during the Covid-19 pandemic.

Based on the problems faced by MSEs, the objectives of this study are to assess the impact of Covid-19 on the performance of MSEs and cooperatives institutions and to formulate a recovery strategies of MSE and cooperative in the new normal era. The output of this research is the strategy for the recovery of MSEs and cooperatives towards a new normal era.

\section{Review of Literature}

\section{Cooperative, Small and Micro Enterprises}

The business world in Indonesia is divided into several types, namely micro, small, medium and large enterprises. According to Law no. 20 of 2008 (UU No 20 tahun 2008) concerning Micro, Small and Medium Enterprises mentions several definitions and criteria for these businesses. Micro enterprises are productive businesses owned by individuals and/or individual business entities that meet the criteria of micro enterprises. Meanwhile, Small Business is a productive economic business that stands alone, which is carried out by individuals or business entities that are not subsidiaries or not branches of companies that are owned, controlled, or are part of, either directly or indirectly, of Medium or Large Enterprises.

Furthermore, the criteria for a Micro Business are: a) having a net assets of not more than IDR 50 million, excluding land and buildings for business premises; or b) have annual sales of no more than IDR.300 million. The criteria for Small Business are: a) having a net worth of more than IDR.50 million up to a maximum of IDR. 500 million excluding land and buildings for business premises; or have annual sales revenue of more than IDR. 300 million to a maximum of IDR. 2.5 billion as shown in Table 1 .

Table 1. Criteria for MSMEs and Large Enterprises based on Assets and Turnover

\begin{tabular}{lll}
\hline \multicolumn{1}{c}{ Business scale } & \multicolumn{1}{c}{ Criteria } & \multicolumn{1}{c}{ Turnover (per year) } \\
\hline Micro & \multicolumn{1}{c}{ Assets (without land and building) } & Max IDR 300 Millions \\
\hline Small & Max IDR 50 Millions & > IDR 300 Millions-IDR 2.5 \\
& & Billions \\
\hline Medium & > IDR 500 Millions-IDR 10 Billions & > IDR 2.5 Billions-IDR 50 Millions \\
\hline Large & > IDR 10 Billions & > IDR 50 Billions \\
\hline
\end{tabular}

Source: Law No.20/2008 on Micro, Small and Medium Enterprises

These various types of businesses are an integral part of the people's economy which has a strategic position, role and potential in realizing a national economic structure that is increasingly balanced, developing and fairer. Each of these types of businesses plays an important role and function in the Indonesian economy. 
Various literatures have stated that micro and small enterprises including cooperatives (MSEC) have an important role in poverty alleviation in Indonesia. MSEC has become a major source of job opportunities and an important source of economic growth. This is based on the very large number, which exceeds 99 percent of the number of existing business units. Another characteristic of this MSEC is that it is relatively spread out to the countryside, labor intensive, uses simple technology, low in capital, has low education, and many are agricultural-based.

One of the studies conducted by Tambunan (2012), in which the study was based on secondary data analysis using poverty and MSE data in the manufacturing industry at the provincial level. The results show the important role of MSEs in poverty reduction as measured indirectly by five indicators: number of business units, number of paid workers, productivity, share of output, and export value. However, their role varies by province as determined by differences in MSE access to important inputs such as education, technical assistance, raw materials and capital.

Corona Virus-19

Corona virus or severe acute respiratory syndrome coronavirus 2 (SARS-CoV-2) is a virus that attacks the respiratory system. This disease due to viral infection is called Covid-19. The Corona virus can cause minor disorders of the respiratory system, severe lung infections, and death. This Corona virus is a new type of corona virus that is transmitted to humans. Even though it mostly affects the elderly, this virus can actually affect anyone, from babies to children to adults, including pregnant women and nursing mothers.

Covid-19 infection was first discovered in the city of Wuhan, China at the end of December 2019. The virus is spreading very quickly and has spread to almost all countries, including Indonesia, in just a few months. This has led several countries to implement policies to impose lockdowns in order to prevent the spread of the Corona virus. In Indonesia itself, a social distancing policy was implemented to reduce the spread of this virus.

Coronavirus is a collection of viruses that can infect the respiratory system. In many cases, this virus causes only minor respiratory infections, such as flu. However, this virus can also cause severe respiratory infections, such as lung infections (pneumonia).

Impact of the Covid-19 Pandemic

Atkenson (2020) conducted research on the impact of Covid-19 in America using the SIR model. The results suggest that the impact of Covid-19 in the United States (and possibly around the world) is that it will be necessary to maintain strict social distancing measures for a year or even 18 months (until a vaccine can be developed) to avoid severe public health consequences.

Another study conducted by PWC (2020) using the GTAP model in Australia shows that the storm of the Covid-19 outbreak has had a negative impact on the Australian economy even in all countries, because Covid-19 has reduced both output and productivity. Australia's GDP will fall by around $1.3 \%$ and household consumption will fall more than that, so it is estimated that in the short term there will be an economic contraction.

Especially in Indonesia, the Covid-19 outbreak is estimated to have a significant impact on the sustainability of MSEC's business in the form of experiencing raw material difficulties, disrupted production processes, even stopping, or market demand that has dropped dramatically. New Normal Condition

Government Regulation No. 21/2020 concerning social distancing in the context of accelerating the handling of Covid-19 has stated that the social distancing is carried out, one of which is by closing the workplace. However, it is impossible for the world of work to be subject to restrictions forever, the wheels of the economy must continue to run. For this reason, after the implementation of the social distancing with the ongoing Covid-19 pandemic conditions, it is necessary to make efforts to mitigate and prepare the workplace as optimally as possible so that they can adapt through lifestyle changes to the Covid-19 or New Normal situation.

The Minister of Health has issued a Minister of Health Decree (KMK) Number

HK.01.07/MENKES/328/2020. The Decree is regarding Guidelines for the Prevention and Control of Covid-19 in Office and Industrial Workplaces in Support of Business Continuity in Pandemic Situations. The KMK, which was issued on May 20, 2020, contains guidelines for 
preventing Covid-19 for workplaces and workers during the social distancing period until it enters the new normal phase after social distancing. In the KMK there are detailed guidelines for workers if they return to work after the end of the social distancing. The guidelines are divided into when traveling to work, while at work and when returning home. By implementing the guidelines in the KMK, it is hoped that the risk and impact of the Covid-19 pandemic can be minimized in the workplace, especially in offices and industries where there is potential for transmission due to the gathering of many people in one location.

MSEC Recovery Strategy

In anticipation of the impact of Covid-19 on MSEC players, the Ministry of Cooperatives and SMEs has prepared 8 special programs. The programs are as follows: 1) proposing a stimulus for the purchasing power of MSME and cooperative products of around IDR. 2 trillion, 2) supporting and making social distancing effective, but at the same time the stalls can run their business well, 3) restructuring program and subsidizing credit interest rates micro enterprises, 4) credit restructuring specifically for cooperatives through The Agency for Revolving Fund Management for Small and Medium Enterprises and Cooperatives (LPDB MSECs), 5) encourage the provision of masks for all, 6) trying to include the micro sector, which is quite large in number and most vulnerable to being affected by Covid-19 in the cluster of recipients of pre-employment cards for daily workers, 7) cash direct assistance, and 8) proposed income tax art (Pph 21 and PPh 25), import income tax, and value added restitution can be relaxed for MSECs.

The Covid-19 outbreak continues to threaten economic and business stability in various countries, including Indonesia. A number of countries such as India and France have imposed lockdowns or restrictions on regional access. The Indonesian government has also implemented social distancing for several regions in Indonesia. The aim is none other than to cut the spread rate of the Covid-19 virus.

This condition of course puts a number of businesses from large to micro scales at risk of going out of business due to lack of buyers. Another problem is the delay in the supply of raw materials as a result of the closure of regional access. Export-import activities in many countries in the world have become disrupted. One of them is export and import in the Agribusiness sector. As a MSECs business actor, actually can see this condition as an opportunity to start a new business. Selling staple goods from the Agribusiness sector which is able to provide benefits in the midst of limited activities. With a strategy of strengthening local products, the SME Agribusiness sector has great potential to be able to meet both the domestic goods market and the export-import market. In Indonesia, business in this field promises huge profits.

Some of the steps that must be considered in starting an agribusiness sector are choosing a business field, preparing a mature business plan to be able to find out the capital needed, planning sales. Keep in mind that the social distancing appeal will disrupt sales of MSECs business offline. Consider selling vegetables, fruit, or livestock online. Even though there is a Corona pandemic, people's food needs must also be fulfilled. For this reason, MSECs players need to complement their sales by means of digital marketing.

A simple way to adapt and deal with this pandemic is to prepare short-term and long-term strategies while continuing to hope that a Covid-19 virus vaccine will soon be found and mass produced. The short-term policy that can be implemented is financial assistance in the form of soft loans or direct cash assistance by involving the government and the private sector. While the long-term strategy is focused on the introduction and use of digital technology for MSECs as well as preparation for entering the Industrial 4.0 era (Pakpahan, 2020).

This study intends to formulate a MSECs Agribusiness strategy towards recovery due to the impact of the Covid-19 pandemic towards a new normal period. It is hoped that the results of this study will issue policy recommendations for the development of the MSECs. Research results related to the role of MSECs in the economy, the impact of economic shocks on MSECs, the impact of the Covid pandemic on the Indonesian economy, MSECs development strategies, and MSECs development policies have been carried out in many academic circles. Research that synergizes the MSECs Agribusiness economic recovery strategy due to the impact of the Covid19 pandemic during the new normal conditions and the Industrial Era 4.0 and finds new policy 
formulations as part of policy recommendations to overcome the impact of Covid-19 has never been carried out specifically in Indonesia, let alone the pandemic. Covid itself is an epidemic that only emerged at the end of 2019. Thus this research has novelty (novelty) assessed from the aspects of the substance and research methodology.

Scope of substance: first, previous research on the development of MSECs, has indeed been carried out several times in various regions in Indonesia. However, no one has yet discussed it further in relation to recovery strategies, especially with the formulation of impact management policies. Second, the new conception and thinking that the development of MSECs Agribusiness now has to change according to new normal conditions which require new things related to health and the Industrial Age 4.0, so that the use of information technology including in marketing must be further developed in supporting the Agribusiness MSECs business.

In the scope of the methodology, this study uses two approaches, namely quantitative with survey research methods analyzed by descriptive statistics and economic analysis. Furthermore, the recovery strategy formulation will become a policy material to be implemented in the development of MSECs.

\section{RESEARCH METHOD}

\section{Location, Data and sources of data}

The locations of this research are several villages in Darmaga and Ciampea SubDistricts, Bogor Regency and Bogor City. The determination of the research location was carried out purposively based on the consideration that MSEs in the two regions had developed quite well. The number of samples interviewed were 63 MSECs. The main data used consists of primary data and supported by secondary data. Primary data was collected twice at different times by means of direct interview to the respondent and supplemented by online survey.

\section{Sampling Method}

The respondents of this research are MSEs and credit savings and loan cooperatives based on sharia. The types of MSEs being interviewed generally come from the food processing and marketing businesses that are suspected of being affected by Covid-19. The number of research samples interviewed was $60 \mathrm{SME}$ units and three cooperatives which were determined purposively.

\section{Method of Analysis}

Data were analyzed quantitatively and qualitatively. The quantitative analysis used is the Before and After Analysis and Marketing Analysis. In the MSE sample, some of the variables measured are those related to business aspects such as turnover, costs and income. These variables were processed using SPSS 16.0 and tested statistically. Data analysis using Paired Samples T-test aimed to test the hypothesis of this study is to know the difference in the condition of the business MSEs before and after the occurrence of a pandemic Covid19. The complete T-test formula for two paired samples (Paired Samples T-test) is as follows:

Where:

$$
t=\frac{\bar{x} 1-\bar{x} 2}{\sqrt{\frac{s_{1}^{2}}{n 1}+\frac{s_{2}^{2}}{n 2}-2 r\left(\frac{s 1}{n 1}\right)\left(\frac{s 2}{n 2}\right)}}
$$

Jurnal Manajemen dan Organisasi

(JMO),
Vol. 12 No. 3 ,

Vol. 12 No. 3 ,

Hal. 220-231

$\mathrm{t}=$ calculated $\mathrm{t}$ value

n2 $=$ number of MSE members after Covid-19

s1 = standard deviation of MSE before Covid-19

$\mathrm{x} 1=$ average value of MSE before Covid-19

s2 = standard deviation of MSE after Covid-19

x2 = average value of MSE after Covid-19

n1 = number of MSE members before Covid-19

$\mathrm{r}=$ correlation coefficient 
The hypotheses in this study are:

H0: There is no significant difference between the financial performance before and after the crisis.

H1: There are significant differences between financial performance before and after the Pandemic Crisis.

From the results of tests performed, then reject $H 0$ if (1) p-value $<\alpha$ and (2) $t$ count $>\mathrm{t}$ table or $-\mathrm{t}$ count <-t table.

\section{RESULTS AND DISCUSSION}

\section{Impact of Covid-19 on MSEs}

In general, apart from affecting health, the Covid-19 pandemic affects the economy, especially MSEs, directly or indirectly and on both the supply and demand sides. On the supply side, MSEs are forced to reduce the use of labour because they have to stay at home due to lockdown policies and restricted movement of people. Actions to control disease by means of lockdown/PSBB and house quarantine to further reduce the spread of Covid-19. However, as a result, the supply chain for raw materials for MSEs businesses has also been cut off (OECD, 2020).

In the same report, the OECD (2020) states that the impact of Covid-19 on the demand side, a dramatic and sudden loss of demand and income, greatly affects the ability to function of MSEs, and/or causes a severe shortage of liquidity. Furthermore, consumers experience decreased income, fear of contagion and increased uncertainty, which in turn reduces spending and consumption.

This effect was exacerbated because many workers were laid off and companies were unable to pay their salaries. Several sectors, such as tourism and transportation, were severely affected, also contributing to dwindling business and consumer confidence. Within the general public in the Regency and City of Bogor, the business sector, which has been closely related to the education sector, is also experiencing a dire condition, because until now offline education activities are still closed. The activities affected include: transportation, food stalls/hawker vendors, renting student rooms, and secondary and tertiary needs traders. More generally, MSEs tends to be more vulnerable to 'social distancing' than other companies.

Figure 1 below describes the business conditions of the MSEs studied. The business performance of the three types of respondents experienced a significant decline after covid-19 compared to before covid-19. This condition occurs both in business turnover, costs and profits. However, not all MSEs have had the negative impact of the Covid-19 pandemic. Businesses engaged in information technology, such as cell phone merchants, credit sellers and laptop/computer services and merchants who have used digital marketing have experienced a very varied increase in sales.

If an outline is drawn, the following are the real impacts caused by Covid-19 on the MSE sector, namely (1) decrease in buying and selling activity, (2) difficult to obtain raw materials, and (3) distribution is hampered. 


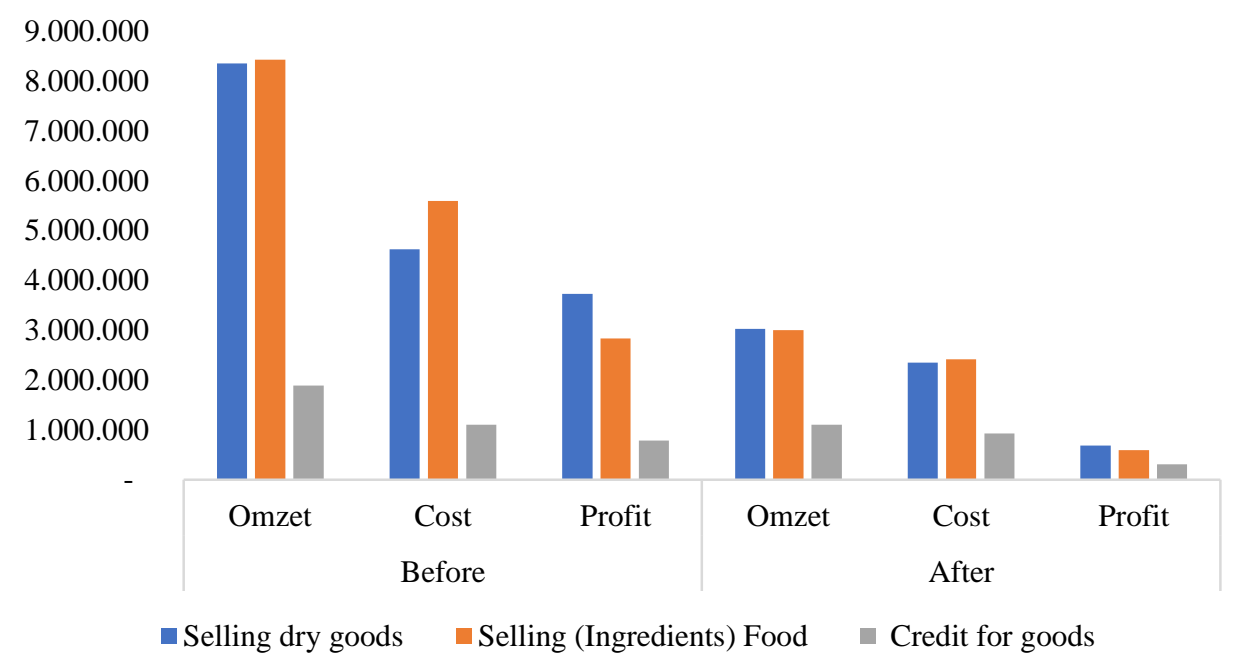

Figure 1. Description of the Respondent's Business

\section{Decrease in buying and selling activity}

Prompts social distancing in order to avoid transmission of the virus Corona wider, to some extent contributed to lower trading activity in the community. As entrepreneurs food stall in Bogor have decrease in turnover by 50 percent. However, like the results of research conducted by the Center for Economic and Social Studies (CESS) and The Center for Micro and Small Enterprise Dynamic (CEMSED) (2012), SMEs in Indonesia are unique because they always have the ability to develop and survive during a crisis ${ }^{1}$. This is evidenced by the initiative of the food stall entrepreneurs who prefer to continue operating, but have changed their way of selling by only serving packaged purchases (to take home), not serving food purchases on the spot.

\section{Difficult to Obtain Raw Materials}

The social distancing policy chosen by the Indonesian government has disrupted production activities. Some companies adopted the work from home (WFH) policy, some decided to lay off their employees, and even layoffs. According to the latest data from the Bogor Regency and City Cooperative Office, 1.213 workers reported having lost their jobs due to mass layoffs, while 12.073 other workers lost their income because they were sent home without wages. This has made the reduction of production capacity in extreme. Like it or not, this condition has led to scarcity of raw materials for home industry production, or to experience extreme price increases.

For example, the SME sector for cake and bread makers is confused by the soaring prices of eggs and sugar. As a result, the selling price of the product was also increased. This choice is considered risky, considering that currently people's purchasing power is sluggish.

\section{Distribution is hampered}

Covid-19 has decreased movement of vehicles in the extreme in the area of Bogor. The cessation of distribution activities is of course very detrimental to SME business players. They are now confused about how to distribute their products, especially for MSEs that have started to expand their market reach outside the region, or even across islands. Especially for those whose job is to sell merchandise from house to house, they also experience obstacles because there are many residential areas, even roads are blocked by residents to reduce the spread of the disease.

\section{Impact on MSEs Costs}

If the MSE business is analyzed, namely by comparing the production costs before the

Jurnal Manajemen dan Organisasi

Vol. 12 No. 3 ,

Vol. 12 No. 3,

Hal. 220-231 pandemic with the after-pandemic, a striking difference will appear. The production cost in question is the total expenditure of MSEs required in carrying out the production process which 
is stated in rupiah units per month (IDR/month). For costs, it was found that the costs of MSEs before the pandemic were higher than those after the pandemic. The results of data processing can be seen in Table 2 .

Table 2. Paired Samples Cost Test Results

\begin{tabular}{lcccc} 
& Mean & $\mathrm{N}$ & $\mathrm{t}$ & $\mathrm{S}$ \\
\hline Before & 4462025.7500 & 60 & 3,004 &, 004 \\
After & 2697729.1667 & 60 & & \\
\hline
\end{tabular}

Source: Primary Data (2020)

From the output above, it can be concluded that there are differences in costs incurred for businesses before and after the pandemic. It can be seen from the table above that there is a reduction in costs. The difference is significant by $\mathrm{t}=3,004$, a significant level $(\alpha)$ of $5 \%$ and $\mathrm{df}$ (degrees of freedom) 59, can be obtained $t$ arithmetic $\geq t$ table $(3,004 \geq 2,093)$. So that the costs needed to run a business are lower than before the pandemic. This is due to lower raw material costs, using less volume. Likewise, labour costs are less, because they have to be reduced. The test results show that the significance of 0.004 base on the value probability ( $\mathrm{sig}<0.05$ ). This means that $\mathrm{HO}$ is rejected and $\mathrm{H} 1$ is accepted with the conclusion that in the population there is a statistically significant difference between the costs incurred for business before and after the pandemic. The same cases also in vegetables business (Pardian et al., 2017).

\section{Income}

Furthermore, if the MSE income is examined by comparing the conditions before and after the Covid-19 pandemic, the results are shown in the following table. The results of data processing can be seen in Table 3 .

Table 3. Result of Paired Samples Income Test

\begin{tabular}{|c|c|c|c|c|}
\hline & Mean & $\mathrm{N}$ & $\mathrm{T}$ & Sig \\
\hline Before & 2539640.9167 & 60 & 4,154 & .000 \\
\hline After & 817687,5000 & 60 & & \\
\hline
\end{tabular}

Source: Primary Data (2020)

From the data above, it can be concluded that there are differences in income obtained before the Covid-19 pandemic and after the pandemic occurs. There seems to be a decrease in income during the pandemic. The significant difference with $t=4,154$, significant level $(\alpha)$ of 5 percent and df (degrees of freedom) 59, can be obtained $t$ arithmetic $\geq t$ table $(4,154 \geq 2,000)$. So that the income earned by MSEs is lower than before the pandemic. This is because the factors that affect income also change, such as turnover and costs. Now almost all of them are affected because of the pandemic and because of the lockdown. The test results show that the significance is 0.000 based on the probability value ( $\mathrm{sig}<0,05$ ). This means that HO is rejected and H1 is accepted with the conclusion that in the population there is a statistically significant difference between the income earned before and after the pandemic.

The Covid-19 pandemic has caused a decrease in the turnover of MSEs, which averaged 62 percent. MSEs are the most threatened group of entities because they do not have sufficient resources to survive the crisis. The consequence of this economic crisis is the increasing role of state intervention and international financial institutions. State policies are taken in the form of postponement of loans and tax payments, takeover of several jobs or social security costs with the central budget, prioritizing safety and disaster management (Fitrisari, 2020).

\section{Impact of Covid-19 on Cooperative}

When linked to the financial markets, the impact could potentially spread viruses affect the financial markets, with diminishing confidence and credit reduction. These impacts affect both large and small scale financial companies. Small-scale financial institutions such as microfinance (savings and loan cooperatives) which operate in rural areas and serve micro and small businesses by "pick-up" also suffer losses. 
Table 4. Description of the Respondent's Credit with Covid-19

\begin{tabular}{lrrr}
\hline Categorizes & Before (\%) & After (\%) & \multicolumn{2}{c}{ Change (\%) } \\
\hline Pass & 73,0 & 18,3 & 54,7 \\
Substandard & 2,3 & 43,3 & $-41,0$ \\
Doubtfull & 6,7 & 16,7 & $-10,0$ \\
Loss & 18,0 & 21,7 & $-3,7$ \\
\hline
\end{tabular}

This loss is due to the level of financing congestion experienced by the cooperative which reaches 55 percent. The development of the cooperative's performance which has experienced a decline is largely due to disruption of customers' businesses. In addition, there was a financing congestion (NPF) of up to 3,46 percent before Covid-19 hit. Financing micro-businesses with a central consultation system consisting of women cannot fully reduce the existing NPF value. This is influenced by several factors, including the use of loan funds that are used for personal gain and consumption, so that the obligation to pay debts is disrupted.

The decrease in turnover of cooperatives was caused by disrupted and stalled returns from MSEs. The risks overshadowing the financial industry in past pandemics, namely lending, asset quality deterioration and tightening the net interest margin.

More specifically, when compared to the condition of sharia cooperatives with conventional cooperatives, it appears that cooperatives in the form of sharia will be more able to survive during the Covid-19 pandemic because they use a profit sharia system. With the profit sharia system, the condition of the balance of Islamic cooperatives in times of crisis due to the Covid-19 pandemic will be elastic because the amount of costs allocated for profit sharing payments will also decrease with a decrease in the income earned by Islamic cooperatives. This is different from conventional cooperatives, where when the decrease in credit interest income is not followed by a decrease in interest costs for depositors, this will be a serious problem for conventional cooperatives.

If the cooperative does not want to distribute new loans, 60 percent of MSEs will seek loans from relatives (children, relatives and neighbours), 25 percent will borrow from other cooperatives even though the interest is high and 15 percent will sell their household assets. The cooperative itself is forced to provide relaxation, make efficiency by reducing employees, and asking for reduced profit sharing payments to creditors.

\section{Recovery Strategy}

Luckily, the government is currently brave enough to take a policy by not imposing a full lockdown, so that some MSEs in the regions still have the opportunity to find ways to 'survive'. In addition, there are several other policies that are considered quite helpful for SME entrepreneurs, for example providing credit relaxation, eliminating electricity and discounts of up to 50 percent, as well as an easy capital injection program.

Open social distancing and WFH policy and replace them with a healthy lifestyle by wearing masks, while maintaining social distancing and washing hands. This needs to be done so that the business climate for MSEs will re-open because very few MSEs are able to afford and take advantage of the market place. However, some MSEs who have opportunities to enter digital marketing need to be encouraged by improving the quality of their products so that they meet standardization requirements, improve product packaging, provide additional capital that is easily accessible to MSEs, and take advantage of existing digital marketing. Because after all, during this pandemic, digitization has become a necessity, especially in the industrial era 4.0. However, according to research Papadopoulos et all (2020) they are still debating the use of the digital technology (DT) strategy to face challenges in response to COVID-19. There is still need to further explore the use of DT in MSEs to ensure business continuity during COVID-19.

In the midst of a crisis like this, many business sectors or Micro and Small Enterprises (MSEs) are struggling to survive. This business is often difficult to survive due to limited capital. The existence of MSEs as a group that is very vulnerable to falling into the abyss of poverty and bankruptcy due to economic shocks or impacts. Therefore, providing venture capital is used as a means of reducing the impact of the crisis. This provision of capital can be done with 
several policy alternatives, such as providing additional stimulation of sharia banking relaxation and restructuring or deferral of sharia credit / financing payments for the next few months. Provision of capital from Islamic banking / financial institutions needs to be supported and strengthened with assistance so that it can be accounted for.

Second, the business capital above can also be followed by free loan. In sharia economic/financial terminology, free loan is a loan that does not take any benefits (profits) but is still emphasized to be repaid. This product/scheme is one of the products/schemes of the Islamic financial system which is very important in supporting the recovery or sustaining the economy. Among the distribution options that can be done are through: (1) Sharia Microfinance Institutions in financing nano businesses where the funds can come from several sources, both from the general public, private companies and State Owned Enterprises/Municipality Owned Corporation (SOE/MOC); (2) direct loans without margin for business or consumption that are channelled by companies (private or government) to employees or partners (such as online motorcycle taxi drivers) where the funds can come from Corporate Social Responsibility (CSR) funds or other posts. To increase CSR funds, the government needs to emphasize the obligations and higher CSR contributions from both SOE/MOC and private companies.

Third, apart from the sharia banking sector and free loan, some of the funds collected by zakat collection units or organizations, especially those in the regions, can be used to strengthen MSEs' businesses. Rescuing a group of MSEs that are in crisis or threatened with bankruptcy due to the economic impact of the Covid-19 outbreak can be categorized as the zakat recipient group, namely as a poor group, struggling in the God way, or people in debt.

Fourth, sharia financial technology development to facilitate the liquidity of the online market participants by sharia, which at the same time also attempted an increased focus on social finance (zakat, donation, charity and endowments) in addition to commercial finance. Including the development of a market place to collect traditional markets and MSEs, which currently number nearly 60 million, with the aim of bringing together demand and supply both at home and abroad, especially during times of lockdown due to pandemics.

\section{CONCLUSION}

The results showed that MSEs had decreased in turnover by an average of 62 percent and saving and loan cooperatives by 55 percent. The decrease in turnover of cooperatives was caused by disrupted and stalled returns from MSEs. Some of the risks overshadowing the financial industry in past pandemics, namely lending, asset quality deterioration and tightening the net interest margin.

More specifically, when compared to the conditions of sharia cooperatives with conventional cooperatives, it appears that cooperatives in the form of sharia will be more able to survive during the Covid-19 pandemic because they use a profit sharia system. With the profit sharing system, the condition of the balance of Islamic cooperatives during the crisis due to the Covid-19 pandemic will be elastic because the mount of costs allocated for profit sharing payments will also decrease with a decrease in the income earned by Islamic cooperatives. This different from conventional cooperatives, where when the decrease in the credit interest income is not followed by a decrease in the interest costs for depositors, this will become a serious land problem for conventional cooperatives.

If the cooperative does not want to distribute new loans, 60 percent of MSEs will seek loans from relatives (children, relatives and neighbours), 25 percent will borrow from other cooperatives even though the interest is high and 15 percent will sell their household assets. The cooperative itself is forced to provide relaxation, make efficiency by reducing employees, and asking for reduced profit sharing payments to creditors. 


\section{REFERENCES}

Albulescu, C (2020). Coronavirus and Oil Price Crash. available at SSRN: https://ssrn.com/abstract=3553452 or http://dx.doi.org/10.2139/ssrn.3553452 (accessed 12 March 2020).

Atkeson, A. (2020). What will be the economic impact of COVID-19 in the US? Rough estimates of disease scenarios. working paper no. 26867. National Bureau of Economic Research, March 2020, available at: https://www.nber.org/system/files/working_papers/w26867/w26867.pdf, (accessed 12 March 2020).

BPS-Statistic of Bogor City. (2019). Gross Regional Domestic of Bogor City. Bogor: BPSBappeda.

BPS-Statistic of Bogor Regency, (2019), Gross Regional Domestic of Bogor Regency. Cibinong: BPS-Bappeda.

Fitriasari, F. (2020). How do Small and Medium Enterprise (SME) survive the COVID-19 outbreak?. Jurnal Inovasi Ekonomi, 5 (2), 53-62.

Lestari, M. (2014). Dampak Krisis Ekonomi dan Masuknya Bank Umum pada Pasar Kredit Usaha Mikro Kecil terhadap Kinerja. KINERJA, 18 (1), 45-63.

Malik, K., Meki, M., Morduch, J., Ogden, T., Quinn, S., \& Said, F. (2020). COVID-19 and the Future of Microfinance: Evidence and Insights from Pakistan. Working paper, Forthcoming, Oxford Review of Economic Policy (special issue), January 2020, available at: https://www.financialaccess.org/publications-index/2020/covid-mfi, (accessed 15 June 2020).

Miswanto \& Vajrin, S., A. (2019). Analisis Kinerja Keuangan: Sesudah dan Sebelum Krisis Ekonomi Global 2008 pada Perusahaan Manufaktur di Indonesia. BALANCE: Jurnal Akuntansi, Auditing dan Keuangan, 16 (1), 22-40.

OECD. (2020). Coronavirus (COVID-19): SME Policy Responses. Tackling Coronavirus (COVID-19): Contributing to a Global Effort. available at: https://www.oecd.org/coronavirus/en/ (accessed 31 May 2020).

Omar, A. R. C., Ishak, S., \& Jusoh, M. A. (2020). The impact of Covid-19 Movement Control Order on SMEs' businesses and survival strategies. GEOGRAFIA OnlineTM Malaysian Journal of Society and Space, 16 (2), 139-150.

Pakpahan, A. K. (2020). COVID-19 dan Implikasi Bagi Usaha Mikro, Kecil, dan Menengah. available at: http://journal.unpar.ac.id/inddex.php/JurnalIlmiahHubunganInternasional/article/download/3870/2903(accessed 31 My 2020).

Papadopoulos, T., Baltas, K. N. \& Balta, M. E. (2020). The use of digital technologies by small and medium enterprises during COVID-19: Implications for theory and practice. International Journal of Information Management, 55(1), 102192.

Pardian, P., Elly, R., Endah, D., \& Bobby, R. S. (2017). Persepsi dan Minat Petani Muda dalam Budidaya Sayuran Swiss Chard Organik. Dharmakarya: Jurnal Aplikasi Ipteks untuk Masyarakat, 6 (3), 163 - 166.

PWC. (2020). The possible economic consequences of a novel coronavirus (COVID-19) pandemic, available at: https://www.pwc.com.au/publications/-australiamatters/economic-consequences-of-coronavirus.html (accessed 29 May 2020).

UU No 20 Tahun 2008 tentang Usaha Mikro, Kecil, dan Menengah (2008), available at: https://www.bi.go.id/id/tentang-bi/uu-bi/.../UU20Tahun2008UMKM.pdf (accessed 29 May 2020). 